\title{
About Arnica Montana Grasslands and their Context
}

\author{
Anca PLEŞA ${ }^{1 *}$, Ioan ROTAR ${ }^{1}$ Florin PĂCURAR ${ }^{1}$, Roxana VIDICAN $^{1}{ }^{1}$ Agnes BALASZI $^{1}$ \\ 1) University of Agricultural Sciences and Veterinary Medicine, Cluj-Napoca, Mănăștur Street nr. 3-5, \\ 400372, Cluj-Napoca, Romania, \\ * corresponding author: ancadorinabogdan@yahoo.com
}

Bulletin USAMV series Agriculture 71(2)/2014

Print ISSN 1843-5246; Electronic ISSN 1843-5386

DOI 10.15835/buasvmcn-agr: 10362

\begin{abstract}
Agriculture is an history of a real symbiosis which developed between crops and man; crops have made it possible to sustain an ever increasing human population. An key question nowadays is how the land can be cultivated and agricultural goods be produced under the conditions of sustainable development, as well as under the EU regulations. In Apuseni Mountains is well known Arnica montana L. system, which annually provides significant income to oligotrophic grasslands owners and thus increases their interest on these systems. The goal is to maintain grassland biodiversity and increasing their production in Apuseni Mountains and find a new management for Arnica montana's oligotrophic grasslands. The existing extensive grassland-based farming systems in Southern Europe are the end product of complex socio-cultural processes, linked with local history and tradition. Even biodiversity has been predominantly considered as a biological concept, although it is possible to link it with cultural and social diversity. Pastures have gained a renewed importance due to the diversities of knowledge, languages and traditions of pastoral people that have been recognised as part of the general diversity.
\end{abstract}

Keywords: Arnica montana, biodiversity, environment, productivity

\section{INTRODUCTION}

Meadow is a major resource in the biosphere that sustains life about a billion people worldwide (Schnyder et al., 2010). With the development of agriculture and the means of production, human intervention in natural grassland ecosystems has increased progressively. Today, physiognomy bands, regardless of their origin, are determined primarily by humans and him livestocks. In industrialized Europe, grassland covers about $30 \%$ of the agricultural area and forms the basis of a strong ruminant livestock sector. How meadows offering is more widely affected by processes that are usually summarized as "global change" (Taube et al., 2010). Intensification of grassland farm management and production of goods and services to their environment are strongly affected by global markets, international developments resulting global information sharing but equally by climate change. These factors are a serious challenge to the functioning of grassland and there is great uncertainty about how it will be maintained in the future.

\section{MATERIALS AND METHODS}

The research has been carried out in Poienile Ursului, Garda de Sus village, Apuseni Mountains. The experience includes five variants in 5 repetitions which are: firs variant (V1)abandonment, the second variant (V2) - traditional mowing, the third variant (V3)- early mowing, variant 4 (V4)-mowing twice per year, and the last variant, (V5)-mimicking grazing by repeated mowing). Floristic studies were performed before mowing after scale vegetation interpretation given by Braun-Blanquet (1932), when Poaceaele were in the flowering stage. The typological grasslands was done after Tucra et al. 1987. For interpretation of the flora were use programs for vegetation data, have used metric and multi-dimensional scaling which is a method well adapted at coordination data which are not normal or arbitrary stairs. For variance analysis and evaluate the effect of treatments applied on grassy carpet we used statistical program after trials created by the company StatSoft. It is developed a wide variety of dependent variables descriptive for statistics, 
broken down by one or more categorical variables is then calculated for such an analysis of variance (F test).

\section{RESULTS AND DISCUSSION}

In the past 20 years has reduced the number of cattle in Europe and large areas of secondary grassland lost forage production function (Gaisler and Pavlu, 2009). Productive potential of permanent grasslands varies by ecological factors, resort (altitude, condition of supply minerals, etc.), floristic composition and applied management, especially fertilization (Porqueddu et al., 2003). Mowing or grazing and are the most important environmental factors that lead structure and composition of plant communities (Rotar et al, 2011). Thus, assumptions about us that this approach would be a link between management practices and vegetation structure between productivity and quality. Arnica montana L. is the "representative" species of the Apuseni Mountains region (Păcurar et al., 2011). It appears in nutritionally poor meadows, weak productive and operated extensively used as pastures and hayfields. The meadows are part of a traditional household-based subsistence high diversity. Because of changes in agricultural practices, the species has decreased in recent decades in Europe. Extensive grazing and extensive grassland management practices were typical subsistencebased agricultural systems. In Apuseni Mountains, Păcurar, 2005, shows that the meadows around the houses are neat and give better yields of dry matter (DM) higher, while the more distant are less neat and give a poor productivity.

After four experimental years, differentiated mowing on Agrostis capillaris L. - Festuca rubra L. phytocoenosis caused changes in the grassy carpet. After statistical processing, the phytocenosisi were differentiates in two floristic groups (Fig. 1).

The first group includes variants V1 (abandoned pasture), V2 (traditional mowing) and V4 (mowing twice a year). The other group consists of mowed early variant (V3) and the variant that mimics grazing, V5.

The analysis results show a high heterogeneity between treatments. Such variants V1, V2 and V4 are consistent with each other and at the same time are heterogeneous to V3, and V5, which in turn are similar to each other.

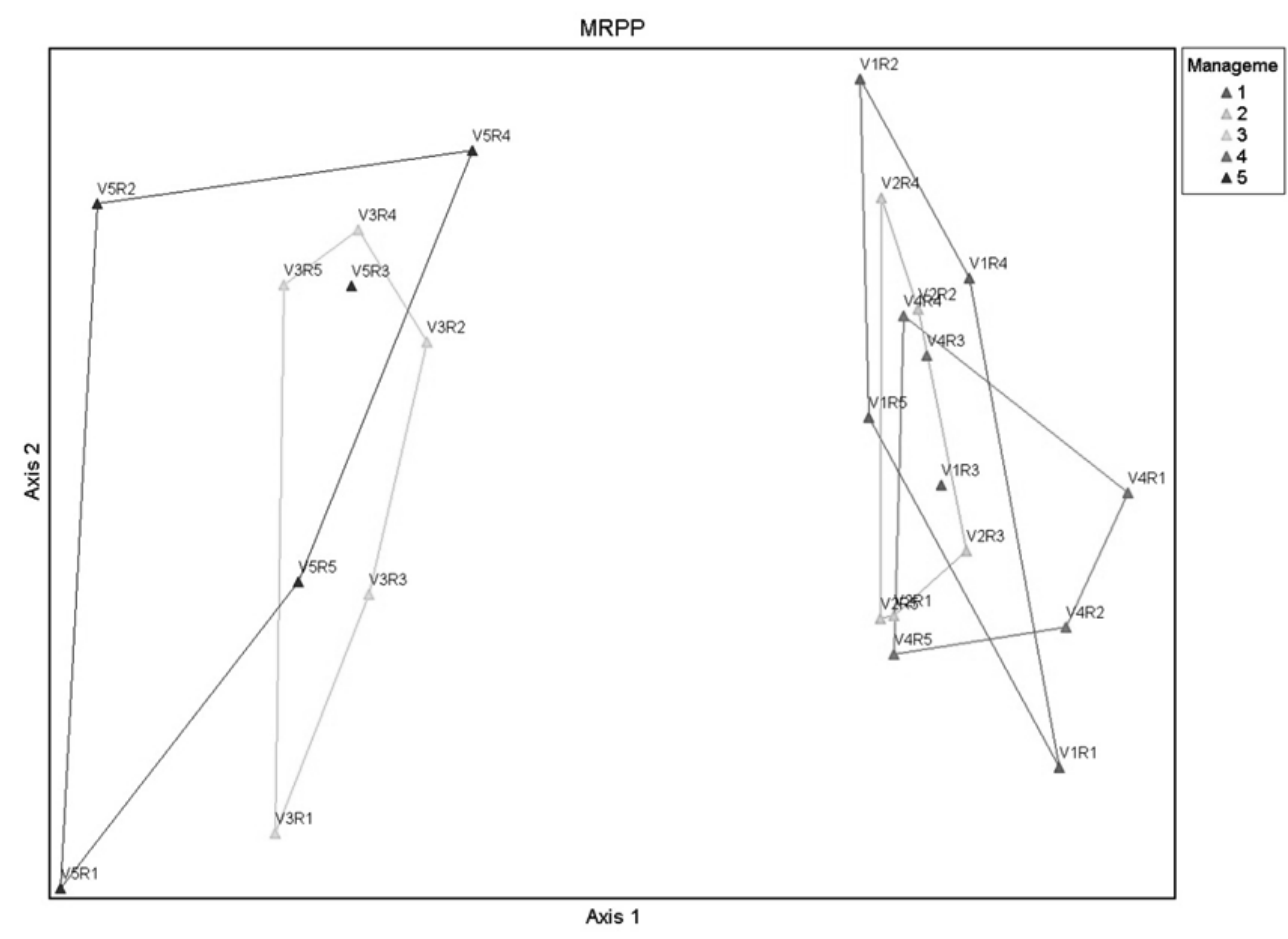

Fig. 1. Ordering floristic composition in 2013, according to the applied management (V-treatment, V1-abandonment, V2 - traditional mowing, V3- early mowing, V4-mowing twice per year, V5-mimicking grazing by repeated mowing) 
Tab. 1. Comparing floristic composition in 2013 of experimental variants based mowing with MRPP (T - T test, A - homogeneous group, $\mathrm{p}$ - statistical significance)

\begin{tabular}{lcccc}
\hline Treatments & T & A & p-value & Significance \\
\hline T1 vs T2 & 1.337 & -0.033 & 0.842 & - \\
\hline T1 vs. T3 & -4.847 & 0.157 & 0.001 & $* * *$ \\
\hline T1 vs. T4 & -0.696 & 0.019 & 0.107 & - \\
\hline T1 vs. T5 & -4.511 & 0.124 & 0.001 & $* *$ \\
\hline T2 vs T3 & -4.534 & 0.172 & 0.002 & $*$ \\
\hline T2 vs. T4 & -1.004 & 0.039 & 0.134 & $*$ \\
\hline T2 vs. T5 & -4.428 & 0.167 & 0.001 & $* *$ \\
\hline T3 vs. T4 & -4.703 & 0.245 & 0.001 & - \\
\hline T3 vs. T5 & 1.182 & -0.021 & 0.767 & $* *$ \\
\hline T4 vs. T5 & -4.553 & 0.170 & 0.001 & $*$ \\
\hline
\end{tabular}

Abandoned variant (V1) and variant 2 (traditionally mown) overlap broadly, but no statistical assurance $(\mathrm{T}=1.337, \mathrm{~A}=-0.033, \mathrm{p}=$ 0.842 , Tab. 1). The same happens in the case of variants V1 (early) and V4 (mowing twice a year) when there is no insurance statistics $(\mathrm{T}=-0.696, \mathrm{~A}$ $=0.019, \mathrm{p}=0.107$ ).

To ensure statistical requires a greater number of repetitions, but their increase is not always possible especially in mountainous regions where land orography is flawed and does not ensure uniformity of the experimental field. Variants V3 (early mowing) and V5 (mimicking grazing by repeated mowing) have no statistical assurance, although quite homogeneous ( $A=-0.021, p>0.05)$.

Comparing abandonment with mowed early variant, we observe that the difference between the two variant is very distinctly significant $(p<0.001)$ and V1 variant drop compared to repeatedly mowed variant (V5) is distinctly significant $(\mathrm{T}=$ -4.511, $\mathrm{A}=0.124, \mathrm{p}<0.001)$. A separate ensure significant $(p<0.01)$ when comparing is mowed traditional variant (V2) as the earlier variant and the variant cuttings $\mathrm{V} 5$, which imitates the grazing $(\mathrm{T}=-4.534 \mathrm{~A}=0.172, \mathrm{p}=0.001$, respectively $\mathrm{T}=$ -4.428, $\mathrm{A}=0.167, \mathrm{p}=0.001$ ).

When compared to traditional mowing twice per year there is a significant difference between the two distinct ensured variants $(\mathrm{T}=-4.703, \mathrm{~A}=$ $0.245, p=0.001$ ). If variant mowed twice a year when compared to the variant that mimics grazing by repeated mowing (at least four times a year) there is a highly significant difference $(\mathrm{T}=-4.553$, $\mathrm{A}=0.170, \mathrm{p}=0.001$ ).

Regarding coverage of Arnica montana L. from experience, in the abandoned variant (V1), that variant which is not never mowing, the Arnica montana L.presence is $4.8 \%$, higher than in mown early variant, which can be explained by the fact that the present data only from the fourth experimental year. In the second variant,V2, variant which is traditional mowing, in August, the coverage of the species Arnica montana. L. came to $7.3 \%$, while in the variant $\mathrm{V} 3$, mowing early, the coverage of the species was $3.2 \%$.

If the variant V4 (variant mowed twice per year) present the highest coverage, $9.8 \%$, as expected, we believe that the species prefers mowing. In variant which was mowed repeatedly, the coverage of the species Arnica montana. L. is $9.0 \%$, less than in traditional mowed variant, but hight contrary to the other variants.

\section{CONCLUSION}

Categories of abandonment caused changes in the phytocenosis recorded herbaceous carpet degradation both in terms of agronomic and ecological point of view.

Valorisation of Arnica montana grasslands, in relation to typical mountain breeds of sheep and cows that give each mountain product (e.g. milk, cheese) their own character and label, would provide the best protection for these old farming systems. 
All these traditional systems contribute tremendously to food security, agricultural biodiversity and the world's natural and cultural heritage.

Acknowledgments. This paper was published under the frame of European Social Fund, Human Resources Development Operational Programme 2007-2013, projectno.POSDRU/159/1.5/S/132765.

\section{REFERENCES}

1. Braun- Blanquet J. 1932. Plant Sociology, the study of plant communities, Ed. Mc-Graw - Hill Book Company, Inc. New - York and London, 31-33

2. Gaiser J., V. Pavlu. 2009. Effect of different mulching regimes on rate of decomposition of aboveground biomass, Alternative Functions of Grassland, European Grassland Federation, vol. 14, ISBN:978-80-86908-15-1, pg.117.

3. Păcurar F. 2005. Cercetări privind dezvoltarea sustenabilă (durabilă) a satului Ghețari, comuna Gârda prin îmbunătăţirea pajiștilor naturale și a unor culturi agricole, Teză de doctorat-USAMV Cluj-Napoca
4. Păcurar F, I. Rotar, Anca Bogdan, Roxana Vidican. 2011. Research Concerning the Structure and Functioning of Low-Input Grassland System, Bulletin USAMV Agriculture 68 (1), 2011, 245-251.

5. Porqueddu C., G. Parente and M. Elsasser. 2003. Potential of grasslands, Grassalnd Science in Europe, vol.8, pg. 1120 2003, Pleven, Bulgaria, 45-46

6. Rotar I., F. Păcurar, Anca Bogdan. 2011. The Influence of Technological Inputs on Arnica montana habitat. Bulletin USAMV Agriculture 68 (1), 2011, 434-435.

7. Schnyder Hans, Friedhelm Taube, Johannes Isselstein. 2010. Foreword of Grassland in a changing world, European Grassland Federation, Kiel, Germany

8. Statsoft, Inc. 2012. Electronic Statistics Textbook. Tulsa, OK: StatSoft. WEB: http://www.statsoft.com/textbook/

9. Taube Friedhelm, Schnyder Hans, Johannes Isselstein. 2010. Foreword of Grassland in a changing world, Kiel, Grassland Science in Europe, Germany

10. Țucra I., Kovacs A. J., Roşu C., Ciubotariu C., Chifu T., Neacşu M., Bărbulescu C., Cardașol V., Popovici D., Simtea N., Motcă Gh., Dragu I., Spirescu M. 1987. Principale tipuri de pajiști din R. S. România, Editura Poligrafică „Bucureştii Noi“. 